\title{
IV Zimowe Forum Onkologiczne w Zakopanem
}

W dniach 15-16 stycznia 2016 roku już po raz czwarty w Zakopanem odbyło się Zimowe Forum Onkologiczne. Składało się z konferencji szkoleniowej PTChO oraz IV Otwartych Zawodów Narciarskich o Puchar Prezesa Towarzystwa.

W tym roku Forum Onkologiczne miało nową, dwudniową formułę oraz wiele nowości programowych. Sesję edukacyjną otworzyli: Prezes PTChO prof. Piotr Rutkowski, prof. Andrzej Stelmach oraz doc. Wojciech Wysocki. Wykład inauguracyjny wygłosił prof. Wojciech Zegarski, omawiając optymalną diagnostykę raka żołądka z punktu widzenia chirurga onkologa.

Następnie odbyła się „Sesja Egzaminacyjna”, nowość tegorocznego Forum, podczas której profesorowie Arkadiusz Jeziorski, Krzysztof Herman, Wojciech Zegarski, Wojciech Polkowski i Andrzej Stelmach przedstawili po dwa pytania z egzaminu ustnego, które sprawiają zdającym specjalizację z chirurgii onkologicznej najwięcej trudności. Podobny charakter miała "Sesja Testowa”, która odbyła się drugiego dnia, gdzie wyżej wymienieni profesorowie omówili po dwa sprawiające szczególne trudności pytania z egzaminu pisemnego.

"Sesję Podhalańską" zainaugurował prof. Edward Towpik, przedstawiając w bardzo interesującej i bogato ilustrowanej prezentacji związki Marii Skłodowskiej-Curie i członków jej rodziny z Tatrami i Zakopanem. Następnie dr Ewa Kalinka-Warzocha, dr Emilia Filipczyk-Cisarż, prof. Arkadiusz Jeziorski, prof. Zbigniew Krasiński i dr Michał Jankowski zaprezentowali tematykę immunoterapii nowotworów, współpracy chirurga onkologa z onkologiem klinicznym w zakresie leczenia ukierunkowanego molekularnie w wy-

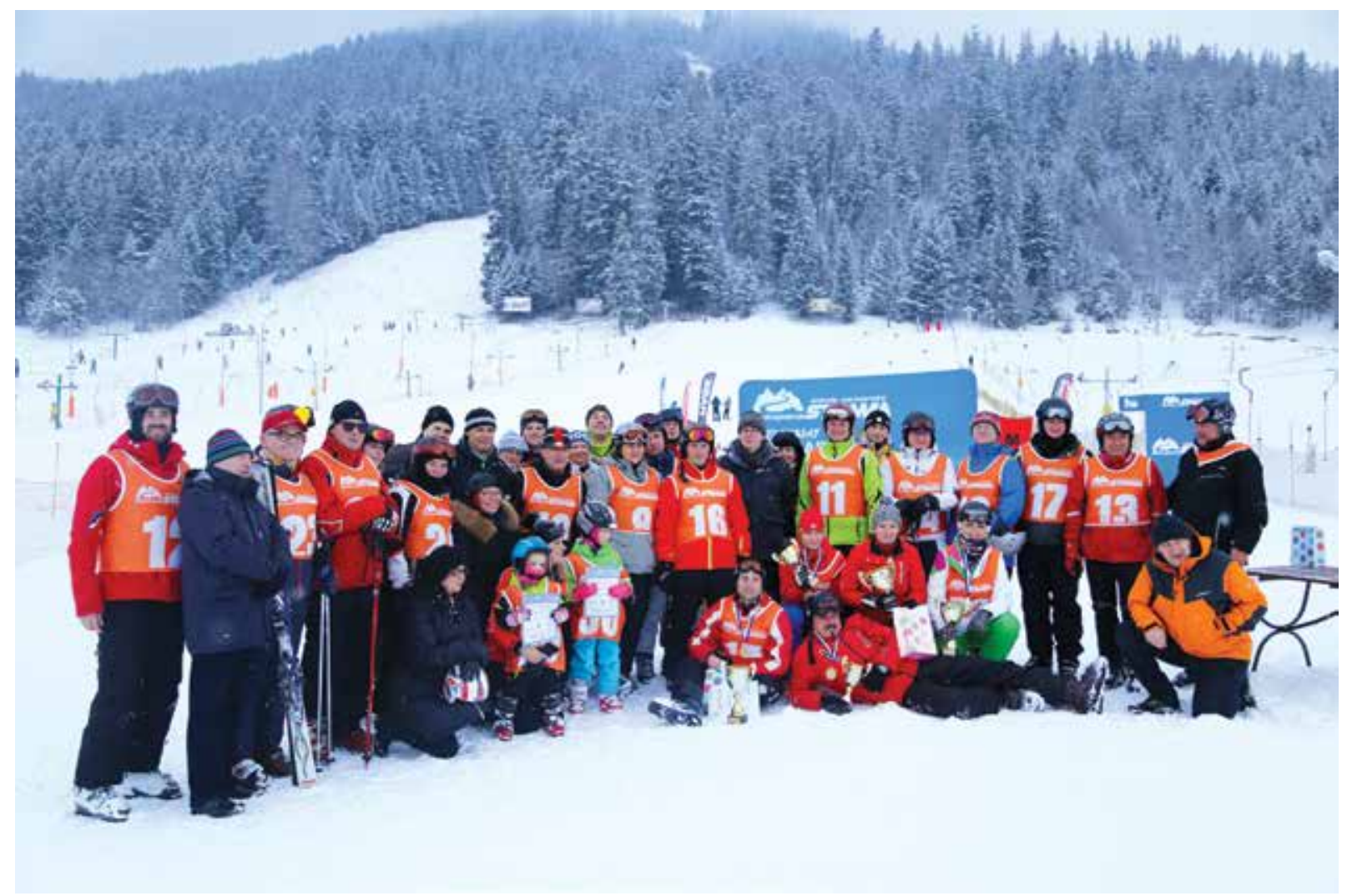

Na stoku — Zawody o Puchar Prezesa PTChO (fot. dr M. Jankowski) 
branych nowotworach, leczenia wielospecjalistycznego chorych na zaawansowanego raka żołądka, przeciwzakrzepowej profilaktyki okołozabiegowej oraz głównych założeń polskiego onkologicznego konsensusu żywieniowego.

Przed rozpoczęciem drugiego dnia Forum na stoku narciarskim pod Nosalem odbyły się IV Otwarte Zawody Narciarskie o Puchar Prezesa PTChO, w których wzięło udział ok. 40 członków i przyjaciół PTChO. Zwycięzcom wręczono puchary oraz pamiątkowe medale. Tytuł mistrzowski po raz czwarty obronił dr hab. Jakub Kenig z III Kliniki Chirurgii Ogólnej UJ CM z Krakowa, który trasę slalomu giganta przejechał najszybciej spośród wszystkich uczestników. Na kolejnych stopniach podium wśród mężczyzn uplasowali się $\mathrm{dr}$ Maciej Naze oraz dr Wojciech Woźny. Wśród pań zwycięstwo odniosła dr Maria Mituś-Kenig z Krakowa, drugie miejsce zajęła studentka medycyny Katarzyna Stelmach z Krakowa, a trzecie miejsce — dr Agnieszka Olchawa z Nowego Sącza. W tym roku po raz pierwszy utworzono także kategorię dzieci; w grupie wystartowało kilku małoletnich zawodników.

Następnie rozpoczęto drugi dzień Konferencji. Prof. Piotr Rutkowski, prof. Wojciech Polkowski, doc. Dawid Murawa oraz dr JoannaWysocka omówili zagadnienia leczenia guzów stromalnych przewodu pokarmowego, kwalifikacji pacjentów do HIPEC, zakresu limfadnektomii u chorych na czerniaka oraz oczekiwań patologa w trakcie współpracy z chirurgiem. Z kolei dr Józef Janczy przedstawił sylwetki chirurgów w historii Tatrzańskiego Ochotniczego Pogotowia Ratunkowego.

Na koniec Forum, na specjalnie zaproszenie w plenarnej debacie wzięli udział: prof. Arkadiusz Jeziorski — konsultant krajowy ds. chirurgii onkologicznej, prof. Piotr Rutkowski - Prezes PTChO oraz prof. Jerzy Jakubowicz — dyrektor Centrum Onkologii — Instytutu im. Marii Skłodowskiej-Curie w Krakowie. Dyskusja obejmowała tematykę finansowania leczenia pacjentów onkologicznych oraz powstającą mapę potrzeb zdrowotnych w Polsce. Ta część spotkania swoją formą odbiegała od typowego charakteru Konferencji, co przydało jej interaktywności i pozwoliło uczestnikom aktywnie uczestniczyć w rozmowie i dzielić się swoimi spostrzeżeniami i problemami.

W Konferencji uczestniczyło łącznie około 80 osób z różnych stron kraju, reprezentujących wszystkie specjalizacje medyczne związane z leczeniem onkologicznym.

Jak co roku, Konferencja miała charakter nieformalny, co przekładało się na możliwość bezpośredniego kontaktu z wykładowcami oraz zachęcało do zadawania pytań i dzielenia się swoimi doświadczeniami z pracy.

Prof. Piotr Rutkowski, prof. Andrzej Stelmach oraz doc. Wojciech Wysocki zamykając sesję podziękowali uczestnikom i zaprosili do ponownego udziału w spotkaniu w przyszłym roku.

Czwarte Zimowe Forum Onkologiczne ponownie potwierdziło swoją rosnącą pozycję w napiętym kalendarzu konferencji oraz zjazdów onkologicznych. Szczególnie nowa formuła oraz tematyka związana z egzaminem z chirurgii onkologicznej okazały się być magnesem przyciągającym chirurgów będących w trakcie specjalizacji. Dlatego gorąco zachęcamy Państwa do udziału w przyszłorocznym spotkaniu, w styczniu 2017 roku.

Dr hab. n. med. Jakub Kenig

III Katedra Chirurgii Ogólnej UJ CM w Krakowie

Dr n. med. Jerzy Władysław Mituś

Centrum Onkologii — Instytut im. Marii Skłodowskiej-Curie

Oddział w Krakowie

Katedra i Zakład Anatomii UJ CM w Kraków

e-mail:jerzy.mitus@gmail.com 